\title{
WSIS, IFLA, UNESCO and GATS: \\ Networking for libraries on an international level
}

\author{
Christel Mahnke \\ Goethe-Institute, Munich, Germany
}

\begin{abstract}
Purpose: The World Summit on the Information Society (WSIS) shows the political dimension of the global information society. This article considers the state of WSIS after the second phase and shows possibilities for libraries to participate in the WSIS implementation. Furthermore, relations between WSIS, GATS and the UNESCO Convention on the Protection and Promotion of the Diversity of Cultural Expressions are explained. IFLA, as leading library organization, as well as national associations, is taking up the challenge of advocating libraries as agencies of information societies.
\end{abstract}

Design/methodology/approach: Report and analysis of WSIS Summit 2003-2005 and WSIS Stocktaking for Libraries.

Findings: Relevance of WSIS Summit 2003-2005 and WSIS Stocktaking for Libraries.

Originality/value: First-hand information on the WSIS process. Proposals for networking between libraries and advocacy for libraries on global political level.

Keywords: Information society, Libraries, Networking

Paper type: Viewpoint

\section{Networking and information politics: WSIS and other fields of action}

For most librarians, networking is part of their daily life. On a national and international level, there are many joint projects and personal contacts made possible and kept alive by e-mail and the Internet. However, libraries are only now becoming aware of their role in the global information society and the new field of information politics.

The World Summit on the Information Society (WSIS) [1] provides an excellent opportunity for librarians in the field of global politics. Since the 1990s, several world summits have been held by UN-Organisations to provide an opportunity to discuss, and hopefully solve, problem issues such as poverty and development, health and food. In 2001, the United Nations (UN) General Assembly decided to hold the first World Summit on the Information Society (WSIS). The first phase took place in Geneva in December 2003, and the second phase in Tunis, from 16 to 18 November 2005.

For librarians, it is easy to see why information should be of international political concern: the world is changing rapidly into a global information society. New technologies are shaping the way we live, learn, work and communicate. WSIS aimed to develop a clear statement of political will and to take concrete steps to establish the foundations for an information society for all, reflecting all the different interests at stake. For the first time, not only governments were part of the summit process, but all stakeholders: all relevant UN bodies and other international organizations, non-governmental organizations, the private sector, civil society, and the media. 
Initially, WSIS was organized by the International Telecommunication Union (ITU), and focused on technical aspects, but with the United Nations Educational, Scientific and Cultural Organization's (UNESCO) active participation, WSIS no longer concentrated exclusively on technical matters, but rather on the cultural and educational impact of information. Also, the role of information in achieving the UN Millennium Goals was examined.

Parallel to the WSIS process, UNESCO actively pursued the development and endorsement of a Convention on the Protection and Promotion of the Diversity of Cultural Expression (UNESCO, 2005). It was approved by the General Conference of UNESCO in October 2005, and laid the foundation for national and international cultural policies.

Protection and development of cultural diversity is a challenge of our time. Societies are increasingly asserting their own cultural values, often firmly dissociating themselves from others in doing so. At the same time, however, mankind is confronted with its common global responsibility more than ever before. The coexistence of cultural fragmentation and globalisation can cause tension, which in turn signifies a new potential for conflict. This calls for a worldwide cultural dialogue between partners with equal rights, the aim being to promote tolerance between various cultures and the appreciation of different national and regional cultural traditions. The Goethe-Institute, as one of the agencies of international cultural dialogue, took part in the shaping of the UNESCO Convention on the Protection and Promotion of the Diversity of Cultural Expression.

GATS (General Agreement on Trade in Services) is a treaty that brings services into the irreversible process of opening world trade for merchandise and setting it free from regulations such as customs tariffs and other market entrance restrictions. All members of the World Trade Organization (WTO) are members of GATS. As far as telecommunication or energy markets are concerned, it makes sense to end state monopolies and allow international competition into domestic markets. However, GATS can be seen as running against national and international cultural policies. In several ways, it can counteract political decisions like providing free schooling for children or inclusive library services. Therefore, librarians and other members of civil society in Germany, such as media or education workers, have spoken in favour of a clear distinction between commercial and public spheres.

EBLIDA, the European Bureau of Library, Information and Documentation Associations, has issued a statement on GATS. According to EBLIDA, libraries or educational institutions risk losing their support from public funds in the country in which they operate, if service markets are open to international competition (EBLIDA, 2005).

\section{WSIS and libraries: Geneva 2003}

The International Federation of Library Associations and Institutions (IFLA) took part in the WSIS process from the very beginning (Haavisto and Lor, 2006). As the leading international body representing the interests of library and information services and their users, IFLA representatives managed to put libraries and their contributions to the global information society on the summit's agenda. The Goethe-Institute, Germany's cultural institution abroad, also took part in the 
summit, as a part of German and international civil society and as member of IFLA.

In November 2003, just before the first phase of WSIS took place in Geneva, IFLA held a preparatory conference under the title "Libraries @ the Heart of the Information Society" (IFLA and SLIR, 2003). Thanks to intense lobbying in the crucial days before the conference, and perfect preparation by Swiss librarians in Geneva, libraries are mentioned in the Geneva Declaration of Principles and the Geneva Plan of Action as important partners for the realization of a democratic and egalitarian information society.

The range of recommended actions for governments covers the connection of rural libraries to information and communication technology (ICT) networks, the creation and development of digital public library and archive services, reviewing national library strategies and legislation, developing a global understanding of the need for "hybrid libraries", and fostering worldwide cooperation between libraries. Promotion of e-literacy skills for all is seen as a future task for all governments, taking advantage of existing facilities such as libraries.

Specific training programmes in the use of ICTs in order to meet the educational needs of information professionals, such as archivists, librarians and other relevant professional groups are also mentioned. Training of information professionals should focus not only on new methods and techniques for the development and provision of information and communication services, but also on relevant management skills to ensure the best use of technologies. Development of content is seen as equally important. All in all, the Geneva Plan of Action is a perfect basis for libraries to develop national and regional strategies and projects.

Unfortunately, not all governments are inclined to follow the plan they agreed upon. In Germany, there is no national library strategy, and the place of libraries is not "@ the Heart of the Information Society", at least not in the eyes of politicians. So far, they are hardly mentioned in the European Union programmes for ICT development. But the libraries themselves have taken up the challenge to show their contribution to the implementation of the WSIS goals. In 2004, IFLA set up a Success Story Database [2]: a showcase of libraries as access points to information, ICT learning centres and agencies for continuing education. The database is searchable online and available on CD-ROM. Many projects are cooperative activities of three or more partners, quite often from different countries.

\section{On the way to Tunis}

Librarians watched closely the preparatory process of the second phase, namely a series of preparatory conferences and meetings of WSIS Working Groups. These groups were set up to find solutions for the most important remaining problems of the first phase: Internet governance and financing of Internet connections in developing countries. But not only governments were preparing for the second phase. Civil society was equally active, discussing, in Germany, topics such as open access, the importance of information commons, bridging the digital divide and gender mainstreaming in the field of ICT. The Heinrich Böll Foundation, a legally independent political foundation affiliated with the Green Party, provided a platform for German Civil Society [3]. A prominent civil society figure on the international stage has been the Communications Rights in the Information 
Society (CRIS) campaign [4]. CRIS has been furthering civil society participation at the WSIS. Other important players, to name but a few examples from a multitude of groups and organizations, have been the OpenWSIS Initiative and the Conference of Non-Governmental Organisations in Consultative Relationship with the United Nations (CONGO).

In November 2005, IFLA held the pre-Summit Conference "Libraries - the Information Society in Action" [5] , in Alexandria. The choice of Bibliotheca Alexandrina as the location for IFLA's conference has a special significance: it was the first major IFLA event ever to take place in the Arab world. Contacts between IFLA and the Arab Federation for Libraries and Information (AFLI) were renewed and will hopefully lead to more co-operation with libraries and other civil society members in the Arab world. The attention and respect librarians gained from official WSIS organizers was reflected in the fact that IFLA's pre-Summit Conference was one of three official side events of the second phase of the World Summit on the Information Society.

The Conference was intended to show that libraries and information services provide societies with a ready-made tool to further the information society and achieve the UN Millennium Development Goals. At the end of the conference, the Alexandria Proclamation on Information Literacy and Lifelong Learning (IFLA, 2005a) and the Alexandria Manifesto on Libraries - the Information Society in Action (IFLA, 2005b) were launched. The manifesto calls on governments and non-governmental organizations (NGO) to invest in library and information services as vital elements of the information society strategies, to support unrestricted access to information and freedom of expression, to promote open access to information and to recognise the importance of information literacy. Obviously, this call did not go unheard: IFLA president Alex Byrne was invited to speak in the plenary session of the WSIS closing session, as one of just a few representatives of civil society.

\section{Tunis: Information society with restricted access}

It is a known fact, that many states in the Arab world, including Maghreb states, have restricted freedom of information [6]. Internet-access is filtered, and some sites by human rights groups are not accessible at all. People are prosecuted if they look up "forbidden" sites. However, Tunisia, as the WSIS host country, welcomed its guests as "the land of civilization, culture and enlightened thinking" [7]. Unfortunately, not all guests were welcome. Some journalists were not allowed to enter the country, others were restricted in their work (IFLA/FAIFE Press Release, 18 November 2005). The Summit itself, which counted about 20,000 participants, was held on a site far from town and under strict isolation from local citizens. Security concerns were the official reason, but it was unclear whose security was at stake. These events did not come as a surprise to librarians, who were aware of restricted freedom of information thanks to the recent report of the IFLA Committee on Free Access to Information and Freedom of Expression (IFLA/FAIFE) on Tunisia (IFLA/FAIFE, 2005).

Some civil society side events, one of which was to take place in the Goethe-Institute, had to be cancelled because Tunisian police would not allow participants to enter. These events only underlined the importance of freedom of information. All European delegations expressed their solidarity. 
There were many librarians present at the conference, some as official delegation members of their governments. They seized on the rich networking possibilities and promoted libraries' achievements and the services they provide in making knowledge and information available.

Summit conferences are much more than plenary sessions and working groups. The exposition ICT4D (Information and Communication Technologies for Development) was a fascinating showcase of best practice and new ideas from all parts of the world: the 100-Dollar-Laptop, developed for poor countries by the Massachusetts Institute of Technology (MIT), was on display, as well as interactive educational websites and mobile health care units for remote areas with Internet access to the best hospitals of the capital. Many development agencies and nearly all UN organizations were present, all in all 250 exhibitors and more than 350 conferences. IFLA had its meeting point at the Global Knowledge Partnership (GKP) [8] stand, the leading international multi-stakeholder network committed to harnessing the potential of information and communication technologies for sustainable and equitable development. The members of this widespread network, ranging from grassroots practitioners to policy-makers, gave interesting insights into their work for development.

\section{Open questions after Tunis}

The three main themes of this summit were Internet governance, financing of the future development of the Internet and, of course, the follow-up to the summit. As to Internet governance, no real solution could be found to the question of who should control the Internet. For the time being, power stays with the Internet Corporation for Assigned Names and Numbers (ICANN), a private company based in the United States. A new body for multi-stakeholder policy dialogue called the Internet Governance Forum (IGF) was set up after the summit to have a closer look at ICANN activities and decisions. Its first meeting will take place in October 2006.

Finance matters were also a point of disagreement. Poor countries called for a Digital Solidarity Fund, but donor countries were rather inclined to use existing development aid funds for the development of Internet infrastructure and capacity building in the field of ICT. Looking back to Geneva, there was at least a growing awareness that commercial interest alone will not be enough to secure convenient and affordable Internet access in all parts of the world. This is best seen in ITU's slogan for Tunis: "We always thought communication a human need - now we know it is a human right".

Civil society members parted from Tunis with mixed feelings. Some judged the results as too superficial, others pointed out the significant presence and lively contribution of civil society. However, the integration of all stakeholders in the WSIS process is seen as a success and will continue in the implementation process.

There are different instruments for WSIS stocktaking, such as a database of all WSIS-related projects (2,648 projects as at 10 March), several websites and a Golden Book intended to promote new commitments and initiatives that stakeholders have announced, during the Tunis phase of the WSIS. 


\section{Next steps for librarians}

The summit has taken place, but the process of implementation is just beginning. Librarians should ensure that they capitalise on the formal recognition, general awareness, and advocacy experience that were gained. In Europe, new initiatives like i2010 - A European Information Society for Growth and Employment [9] and i2010 Digital Libraries Initiative [10] are being launched. During the public consultation, librarians gave their opinions on this new information society strategy. In March 2006, a High Level Expert Group on Digital Libraries was established. The group will advise the European Commission on how to tackle key challenges in making Europe's cultural heritage available online.

Over the next few years, we will have to develop new ideas and tools for library advocacy at every level of society. Networking on a European and a global scale will be crucial if we are to make an impact. It is more necessary than ever, that librarians speak with one voice. The German Federal Union of German Library and Information Associations (Bibliothek \& Information Deutschland - BID) brings together libraries, librarians and information experts with supporting institutions. One of BID's main fields of action is international co-operation in the field of librarianship.

IFLA will remain the most important partner on an international level. German participation in IFLA activities is lively and will surely increase over the coming years, with Claudia Lux as the incoming president. UNESCO, with its impressive range of library projects, is also a good and reliable partner for the shaping of tomorrow's information societies. The UNESCO libraries portal [11] gives an overview and project information.

Librarians are active in building a user-friendly, inclusive information society. Through their networks, they are linked to all layers of society and can influence information policy on a local and a global level.

\section{Notes}

1. www.itu.int/wsis/

2. http://fmp-web.unil.ch/IFLA/

3. www.worldsummit2003.org/

4. www.crisinfo.org/

5. www.bibalex.org/wsisalex/agenda.htm

6. www.grc.ae/?sec=Arab+Human+Development+Report\&sec_type=h\&sub_opt= 181

7. www.smsitunis2005.org/plateforme/index.php?lang=en

8. www.globalknowledge.org/

9. http://europa.eu.int/information_society/eeurope/i2010/index_en.htm

10. http://europa.eu.int/information_society/activities/digital_libraries/index_en.htm

11. http://portal.unesco.org/ci/en/ev.phpURL_ID=6513\&URL_DO=DO_TOPIC\&URL_SECTION=201.html 


\section{References}

European Bureau of Library, Information and Documentation Associations (EBLIDA) (2005), Statement on the Proposal of the European Parliament and of the Council for a Directive on Services in the Internal Market, November 2005 , available at: www.eblida.org/position/ServicesDirective_Statement_Nov05.htm (accessed 5 April 2006).

Haavisto, T. and Lor, P.J. (2006), "IFLA in action at WSIS", available at: www.ifla.org/lll/wsis/WSIS-report27-01-2006.html (accessed 5 April 2006).

IFLA Committee on Free Access to Information and Freedom of Expression (IFLA/FAIFE) (18 November 2005), "IFLA protests crack down of intellectual freedom in Tunisia", Press Release, available at: www.ifla.org/V/press/Pr-18112005.htm (accessed 5 April 2006).

IFLA Committee on Free Access to Information and Freedom of Expression (IFLA/FAIFE) (2005), "Report on IFEX - TMG Mission to Tunis", available at: www.ifla.org/faife/faife/tunis-report2005.htm (accessed 5 April 2006).

International Federation of Library Associations and Institutions (IFLA) (2005a), Alexandria Proclamation on Information Literacy and Lifelong Learning, available at: www.ifla.org/lll/wsis/BeaconInfSoc.html (accessed 5 April 2006).

International Federation of Library Associations and Institutions (IFLA) (2005b), Alexandria Manifesto on Libraries, the Information Society in Action, available at: www.ifla.org/ll//wsis/AlexandriaManifesto.html (accessed 5 April 2006).

International Federation of Library Associations and Institutions (IFLA) and Swiss Librarians for International Relations (SLIR) (2003), Libraries @ the Heart of the Information Society, Proceedings of the IFLA Pre-World Summit Conference, Geneva, 3-4 November 2003, available at: www.ifla.org/lll/wsis/proceedings2003.pdf (accessed 5 April 2006).

United Nations Educational, Scientific and Cultural Organization (UNESCO) (2005), Convention on the Protection and Promotion of the Diversity of Cultural Expression, October 2005, available at: http://unesdoc.unesco.org/images/0014/001429/142919e.pdf (accessed 27 April 2006). 